\title{
A Study of Female Consciousness in Shakespeare's The Taming of the Shrew
}

\author{
Yingchun Zhang ${ }^{1, *}$ \\ ${ }^{1}$ College English Teaching Department, Zaozhuang University, Zaozhuang, Shandong 277160, China \\ *Corresponding author. Email: zhangyingchun1981@163.com
}

\begin{abstract}
The Taming of the Shrew is an early play by William Shakespeare. The feminism and consciousness presented in this work are controversial, and the modern readers and drama critics have different opinions on it. This paper will take Shakespeare's The Taming of the Shrew as the main research object, focusing on the female consciousness in it. And this paper will analyze the performance of female consciousness at that time through interpreting the female characters in The Taming of the Shrew, so as to provide some reference for a better understanding of Shakespeare's view of women. In the end, it is concluded that Shakespeare's view of women is full of humanistic care and it is valuable in the historical background at that time.
\end{abstract}

\section{Keywords: Shakespeare, drama, The Taming of the Shrew, female consciousness}

\section{INTRODUCTION}

The Taming of the Shrew is a comedy written by Shakespeare in his early years. It tells the story of Katherina, the shrew, who was tamed by Petruchio and became a good wife. The play consists of a prologue and five acts. The prologue is based on Arabian Nights, and the content of the five act drama is based on the Scottish folk song "a wife wrapped in a horse skin". This combination of multiple sources makes the work full of changes in structure, and highlights Shakespeare's thinking on the social phenomenon of "taming" through the thematic Interpretation in different contexts of the times. From the point of view of the basic plot, "taming" which is based on Scottish folk songs is essentially a social bad habit of western men taming women by various means at that time. Although this work retains the "taming" story frame, it is rich in Shakespeare's unique artistic approach in content expression. By means of positive expression and negative expression, this paper tells people about women's view full of humanistic feelings.

\section{AN ANALYSIS OF THE PLOT AND OVERALL STRUCTURE OF THE TAMING OF THE SHREW}

In the prologue, a cynical aristocrat is playing tricks on a drunk, providing him with a good living environment and a servant waiting for him at any time, so that he mistakenly thinks that he is an aristocrat with amnesia. When he enjoys the noble life, the servants of his family also give him a "taming" comedy, which paves the way for the beginning of the play. With the beginning of the drama, two gentlemen from Padua, Gremio and Hortensio, propose to Bianca, the youngest daughter of the local rich Baptista. However, the rich man proposes that if he wants to marry his youngest daughter, he must wait until his eldest daughter, Catherine, gets married first. Petruchio, Hortensio's friend, happens to get married only by one standard, that is, money, and the rest don't mind. So Hortensio introduced Petruchio to Katherina. In the contact between them, although Katherina, who is fierce in character, has a rude attitude towards Petruchio, Petruchio is still recognized her rhetoric by her through . After their marriage, Petruchio came up with all kinds of absurd "treatments" in order to make Katherina become gentle and virtuous, and let Katherina obey him gradually. So far, Petruchio completed the process of "taming his wife".

Another clue in the play revolves around the love of Bianca, the younger sister. Hortensio and others enthusiastically pursued the virtuous Bianca. They tried to win the favor of Bianca in a variety of ways. Finally, Bianca chose the more desirable Lucentio and secretly marries him without his father's consent. In the last scene, Lucentio and Petruchio made a bet on whose wife is more obedient. Unexpectedly, Katerina, who has always been tough, is the most obedient. She even made 
some remarks about female virtues, "your husband is your master, your life, your owner, your mind and your monarch" [1].

Through the synopsis of the plot, we can see that Shakespeare adopts the nested form of the play in dealing with the overall structure of the play. The beginning of the prelude is the farce, which makes the main play develop on the basis of absurdity and sets the absurdity tone for the following plot. This arrangement of plot structure not only implies the content that women are "tamed"is absurd, but also reflects Shakespeare's negation of the content. The exaggeration in the dramatic state shows Shakespeare's ridicule of patriarchy which is under the protection of feudal autocracy. Katherina's naked words about supremacy of husband's power seem to be women's submission to male power, but in fact they are laughing and scolding at the oppression of women by male power. This is exactly the irony left by Shakespeare and the estrangement effect expected. This is not to convey Shakespeare's own view of women, but to make a strong irony.

\section{FeMALE IMAGE BUILDING IN THE TAMING OF THE SHREW}

\section{A. Katherina in the image of "Shrew"}

Katherina, as the object of taming, has been portrayed as a typical shrew from the beginning. She is "domineering, irascible, moody, vulgar and likes to use violence" [2]. Her words and deeds are outrageous and fierce, which is opposite to the female image of the society at that time. She is not recognized by the society and is popular Known as "dragon lady" and "living hell", her father also called her "a bitch like a devil" [1].

But under the image of "Shrew", Katherina is actually a sensitive and insecure woman. The shrew image she shows is actually the self-protection of her marriage independence. In the play, her father obviously prefers her younger sister. In order to keep her younger daughter from being influenced by her elder daughter, she even wants to marry Katherina out with a high dowry. Under this attitude, Katherina can only constantly protect herself from not being welcomed by men with the external image of "Shrew", so as to avoid her marriage becoming the victim of arranged marriage.

At the same time, under the image of "Shrew", Shakespeare also endows Katherina with agility and boldness. For example, in the first scene of the second act, Katherina has the upper hand in the tit for tat conversation between Katherina and Petruchio. This shows that Katherina is not simply stupid in character, but a selective portrayal of her own image. When Petruchio tames Katherina through a series of means, she shows the image of obedience. This huge difference between the images makes people guess that although Katherine has always been a shrew in her external image, she may still be a woman who succumbs to male chauvinism in her inner heart. But Shakespeare didn't give Katherine the inner monologue lines under this image, but gave a certain space for drama. Katherine's final remarks on "women's morality" superficially affirmed male chauvinism and completely submitted to male chauvinism. It is not difficult to see that Shakespeare actually "expressed negative content in this extremely positive form" [3].

On the whole, Katherina is portrayed as a typical shrew image, which provides an object for the theme of "taming the Shrew". However, from many details of the plot, Katherina's shrew image is not monotonous, but shows the shining point of independent women, which forms a sharp contrast with her sister Bianca.

\section{B. Bianca in the image of "new women"}

In this work, the image of Bianca is in sharp contrast with her sister, Katherina. Different from her sister's arrogance, Bianca is a typical lady. She is gentle and obedient to her father and shows little docility in social places, which makes her deeply loved by her father. Therefore, many pursuers come to her. But under her gentle and virtuous external image, there is a woman with firm character and independent personality. She didn't agree with her father's arranged marriage, and through her own wisdom, she secretly married her sweetheart in her own form. This kind of behavior and attitude of self-control of marriage is completely inconsistent with the image of a good girl. In the last scene, she disdains the obedience of her elder sister Katherina to her husband after she is tamed. All these show Bianca's understanding and pursuit of marriage under the guidance of independent personality.

\section{FEMALE CONSCIOUSNESS IN THE TAMING OF THE SHREW}

\section{A. The sorrow of female consciousness}

Herzlett said "the striking feature of Shakespeare's mind is its typicality"[4]. This typicality is reflected in that the characters in Shakespeare's works are highly abstract and typical, so they are highly representative beyond the dimension of time and space. Taking the two characters in The Taming of the Shrew as an example, we can see that both their external image and the fate of the characters are not unfamiliar to us today. It seems that they are still the real living situation of women in today's society, which means that Shakespeare's comedy is actually a human 
tragedy that has never changed for hundreds of years.

Specifically, the tragedy of women in this work is firstly reflected in the fact that the individual's external role-playing is not decided by themselves, but by men's decision and influence. "Women are imbued with the idea of chastity from an early age, and take it as their own model. If they violate it, they are not regarded as women, but as terrible 'non women' or 'shrews'" [5]. Any woman's tough external resistance will be labeled as "shrew", and therefore will face the unfortunate fate of being "tamed". Just like Katherina in the play, for selfprotection, she constantly declares her arrogance. However, this image is not her own nature, and the struggle itself is still the external manifestation of her female consciousness constantly oppressed.

Secondly, the tragedy of women's consciousness is also reflected in the loss of women's right to choose their own marriage. In this work, Katherine and Bianca, who are from rich families, do not have much choice in the face of their father's arranged marriage, which makes the lack of freedom in marriage the biggest shackle of their female consciousness. When one of them is sought after because of virtue and the other is ignored because of shrew, their female identity value is actually influenced by male patriarchy. For the sake of money, the man who wants to marry her does not regard her as an equal relationship, but more like a gift outside the interest transaction. The inequality of marriage relationship is the absolute expression of the high oppression of female consciousness.

Finally, the imbalance of gender status in marriage is the biggest sorrow for women. After marriage, because her character does not conform to the standards of male dominated society, Katherina has to face the taming like animals, which in essence becomes a kind of naked gender oppression. "The motive of 'taming a wife' itself includes the control of women and the desire of men to build women from their own gender." [6] At the end of the plot, the three men show off their wives to each other about who is more obedient, which more obviously reveals that this kind of unequal gender relationship has formed a long-term oppression in society. The theme of "taming" is still not out of date today, and it also reflects that the true equality in marriage is still not achieved.

\section{B. The relationship between "shrew" and "obedient woman"}

The two female characters portrayed in this play have prominent contradictory relationship in external image and internal consciousness. The attitude of the two sisters towards marriage shows that the so-called "shrew" and "obedient woman" are actually a false proposition.

Specifically speaking, Katherina initially showed her arrogant and strong personality, which is not the performance of her own consciousness, but more like a kind of compromise and selfprotection under the measure of patriarchal social value. After being tamed after marriage, Katherina's obedience to her husband reveals her true thoughts and character. Although Bianca is gentle and virtuous on the surface, it shows that she is the real "Shrew" whether it is her independent personality who dares to choose her own marriage or her disdain for her sister's obedient image after marriage. As a result, the two corresponding female images show a self contradictory female consciousness. This shows that the female image advocated by Shakespeare is not independent and arrogant on the external image, but independent and powerful in the heart. It is a new female who dares to express herself externally and adhere to her nature internally.

\section{Shakespeare's view of women in historical context}

The creation of any literary works is bound to be influenced by the background of the author's time. Therefore, when analyzing Shakespeare's view of women and the female consciousness in his works, we must interpret it in combination with the cognition of women's social orientation in Shakespeare's time. Specifically speaking, Shakespeare was in the Elizabethan period during which the female king had been in power for a long time and women's social status had been significantly improved. Women in this period began to show their pursuit of independent status, which is the real source of this work. However, due to the limitations of the times, the discourse power of the society at that time was controlled by men, and the relative taming theme was more in line with the mainstream values of the times. Therefore, there are a lot of elements advocating that men are superior to women in this work, which is also the main content attacked by later critics. However, from the perspective of artistic treatment in Shakespeare's works, whether the absurd nature of the play in the actual metaphor of the prelude or the soft means used by Petruchio in the process of "taming" all show Shakespeare's humanistic view of women. Although there are limitations in Shakespeare's feminist consciousness, his feminist consciousness cannot be ignored in terms of his time background.

\section{CONCLUSION}

In the structure layout of The Taming of the Shrew, Shakespeare adopted the play in the play, 
starting with absurdity, implying that the content of "taming the Shrew" in the play is also absurdity. In the play, Shakespeare makes Katherina, who is fierce against male chauvinism, completely obedient. The degree that she affirms male chauvinism and her submission to male chauvinism is ridiculous, which shows Shakespeare's satire and ridicule of male chauvinism under feudal autocracy. Bianca is in sharp contrast with her sister. She is obedient on the outside and tough on the inside. Her attitude and behavior on marriage is really a "Shrew" style. Shakespeare made the two sisters show their pursuit of personality independence from different levels which reveals Shakespeare's view of women is full of humanistic care. In the historical background at that time, it is valuable.

\section{References}

[1] William Shakespeare. The Taming of the Shrew [M]. Trans. Zhu Shenghao. Beijing: Beijing United Publishing Company, 2016

[2] Ruan Shiqin. Game and Discipline: A Study on the Construction of Gender Image in Shakespeare's The Taming of the Shrew [J]. Journal of GuangDong University of Petrochemical Technology, 2020,30 (02): 57

[3] Song Xiuhua. Interpretation of the Artistic Charm and Characteristics of The Taming of the Shrew [J]. Drama Literature, 2015,10:97

[4] Shakespeare. The Taming of the Shrew [M]. First Edition. Translated by Zou Minggui. Xi'an JiaoTong University Press. August 2008

[5] Ge Can. Interpreting the Image of "Shrew" from The Taming the Shrew $[\mathrm{J}]$. Journal of Changsha University. 2012.7: 97

[6] Yang Xiaolian, Zhang Lixia. Shakespeare's Male Chauvinism in The Taming of the Shrew [J]. Journal of Chongqing University of Arts and Sciences. 2010.3:61 